Original Research Paper

\title{
Impact of Financial and Trade Openness on Financial Development in Emerging Market Economies: The Case of Turkey
}

\author{
Esin Cakan
}

Department of Economics, University of New Haven, West Haven, CT 06516, USA

Email: ecakan@newhaven.edu

\section{Introduction}

In this study, we aim to investigate the sources of financial development for an emerging market economy and relief an evidence whether financial and trade openness lead financial development in an emerging market structure as in Turkey. Considering the contradictory evidence for the financial development and its impact on the economic growth (Levine, 1997; 2005; King and Levine, 1993; Levine et al., 2000; Beck et al., 2000; Demirgüç-Kunt and Levine, 1996; Demirgüç-Kunt and Maksimovic, 1996; Rajan and Zingales, 2001), we only aim to examine the casual relationship of different measurement of financial openness and financial development, but not its impact on economic growth. Researchers and policy makers have debated on the role of foreign capital and the effects of financial liberalization (stock market or capital account) on economic stability and growth after the turmoil of Mexico currency crises in 1994, Southeast Asia crises in 1997 and Russian government bond default in 199. The general belief was the huge impact of financial liberalization would help the investors to supply more funds to the domestic business which will help to increase investment causing economic growth. The strong link between financial liberalization and economic growth made a lot of countries to open their financial markets to the rest of the world without imposing any restrictions. Although financial liberalization might affect the economic growth, the main question in the chain is whether or not that financial liberalization in the form of financial openness and trade openness would cause any financial development in an emerging market such as Turkey. More than three decades the Turkey liberalized foreign trade choosing export-led growth model while the economy has been showing very volatile performance. When it became to 1990's, the capital accounts were completely liberalized while capital flows as in the high records and tariffs were lowered. In the period of financial liberalization, Turkey experienced three major financial crises due to trade deficits and as a result of these turmoils economic recession was inevitable.

This paper contributes to the literature in two ways. First, unlike the other papers, we study an emerging market which showed high willingness to liberalize her financial markets in the early 1980's. Her experience would be much different than a developed economy. Our study examines the annual data for an emerging market economy, Turkey, from 1974 to 2014 which is a long 
span of data for an emerging economy. Turkey also has been experienced a huge foreign portfolio investment during the last decade, where it is $65 \%$ of the stock market (BIST) is owned by foreign institutional investors. Second, we use ARDL the bounds testing approach to cointegration, developed by Pesaran et al. (2001) that is used to test the existence of a long-run relationship and has small sample properties that are far superior than that of the other cointegration techniques (All the estimations are done by using STATA 12.1 and MicroFit 5.0 (by Peseran and Peseran). ARDL results are much realiable than the traditional cointegration tests.

The remainder of the paper is as follows. Section 2 reviews the related literature, where section 3 provides an introduction to our data and measures (indicators) of financial openness and financial development, a brief description of our data and aggregate index measures is included. Section 4 summaries the methodology and section 5 discusses our empirical models and estimation procedures. Section 6 concludes.

\section{Literature Review}

Financial development literature develops on financial liberalization, which is proxied by privatizations and banking sector reforms and its effects on economic variables, for instances, interest rates and economic growth are dominated by financial control on banking sector (McKinnon, 2010; Shaw, 1973). The financial liberalization as the constraints relaxation, elimination of interest rate controls; lowering of bank reserve requirements; reduction of government interference in banks' lending decisions; privatization of nationalized banks, introduction of foreign bank competition, facilitation and encouragement of capital inflows (Beim and Calomiris, 2001). Using eighty seven countries for industrialized and less developed countries during the period from 1976 to 1995 , Klein and Olivei (2008) find that capital account liberalization strengthens a country's financial system and it has a big role in the developed countries' economic growth. On the other hand, they did not find the same effect of that financial liberalization on financial development for small economies. Svaleryd and Vlachos (2002) find evidence of causal effect of trade openness to financial development. More, Huang (2006) also shows empirical evidence of financial openness impact to explain cross-country differences in financial system development. Similar to the above studies, Kaminsky and Schmukler (2002) create a list of time table for financial liberalization in 28 countries covering different properties of liberalization, for example, the deregulation of the capital account, the domestic financial sector and the stock market. The study categorizes a country fully liberalized if at least two sectors are fully liberalized and the third one is partially liberalized. A country is named as partially liberalized if at least two sectors are partially liberalized.
The finance and economic growth literature is immense. However, there are not many studies examining the relationship between financial development and financial liberalization. One of the first studies in the literature, Borensztein et al. (1998) examines if economies that has greater financial integration show better financial development by investigating the effect of lack of financial integration. Another study that examines the banking sector liberalization effect, Laeven (2000) finds strong evidence of removing banking restrictions on decreasing the financial restrictions and stimulating investment and financial development. More, Demirguc-Kunt et al. (1998) also uses banking deregulation and find that unrestricted banking system is essential for a stronger domestic banking systems with better service to the countries' citizens and it decrease the profitability of the non-foreigner banks. To observe the relationship between financial development and capital controls, Chinn and Ito (2002) create a measurement that relates the amount of capital control. There are different financial development proxies in the literature. The first proxy is the private credit creation and the activity of the capital markets. This measure shows the is link of financial development to the existence of capital controls. Chinn and Ito (2002) shows that this measure can be useful only in an environment characterized by a combination of a higher level of legal and institutional development will the link between financial openness and financial development be readily detectable. Extending the study, Chinn and Ito (2005) focus on the capital account liberalization, legal and institutional development and financial development, especially that in equity markets over the period of 1980 to 2000 by utilizing 108 countries as panel data. Their empirical results of considering several dimensions of the financial sector reveals that a higher level of financial openness contributes to the development of equity markets only if a threshold level of general legal systems and institutions is attained. The most important finding of the study is that financial openness increases by the less corruption and stronger bureaucratic quality in the country.

Some studies examine the financial development relationship with economic growth. For example, by investigating 21 African countries, Ozturk and Acaravci (2013) reveals that financial development has limited effect on economic growth for most of the countries. Addition to that, Petkovski and Kjosevski (2014) examines Central and South Eastern European countries by utilizing GMM dynamic panel model for ratio of bank credits in private sector, interest rates and Ratio of Quasi Money (RQM). They find evidence of Ratio of Quasi Money (RQM), a proxy of financial, openness impact on economic growth. Using a panel encompassing 108 countries from 1980 to 2000, Chinn and Ito (2006) analyze the impact of financial openness's predictive power on financial development. Their results support that 
a higher level of financial openness shoots stock market development under the circumstances of a threshold level of legal development and trade openness is a prerequisite for capital account liberalization while banking system development is a precondition for equity market development. On the other hand, Baltagi et al. (2009) finds empirical evidence for financial development with the help of trade and financial openness. They also find relatively closed economies benefits from liberalizing their trade and capital accounts. However, their findings do not hold support for trade openness. Their empirical results is not under the same conclusion of Rajan and Zingales (2001), the claim of that tarde and financial openness are the main determinants of financial development. Kim et al. (2010) study the dynamic effects of trade openness on financial development for 88 countries over 1960-2005 by utilizing Pesaran et al. (1999)'s Pooled Mean Group (PMG) approach. They find different results for low-income and high-inflation economies in the case of long-run relationship between trade openness and financial development. Therefore, the literature do not have consistent results about openness (trade and financial) and its impact on financial development. Most of the studies uses panel data approach due to the fact of small sample of the country data. Therefore, this study contributes to literature to close the gap of estimation model by using a small sample one country ARDL model.

There are some studies who examined the financial liberalization period during the financial liberalization in Turkey. For example, Acikgoz and Mert (2014) analyze the financial development indicators using openness measurements by using ARDL model for the period from 1980:01 to 2007:2 using quarterly Turkish data. They find that both openness indicators have predictive power on financial development. However, they did not take into account foreign direct investment and use shorter period of time than this study.

\section{Data}

The annual time series data for Turkey is downloaded from the online source of World Bank (WDI) data set; and Federal Reserve Economic Data (FRED) from 1974 to 2014. The data is available for forty years. Furthermore, Hakkio and Rush (1991) shows that using the quarterly and monthly data higher number of observations will not contribute to the robustness of the result in the cointegration analysis. Individual indicators of financial openness and financial development are discussed. Following Creane et al. (2003), it is used three different measures of financial development as follows: (1) Liquidity Liabilities (LLY); (2) the ratio of credit to private sector to nominal GDP (PRIVO); (3) the ratio of commercial bank assets to the sum of commercial bank and central bank assets (BTOT). Additionally, broad money (M2) ratio to nominal GDP is also used, suggested by King and Levine (1993). Theoretically, the increase in M2 to GDP ratio shows the increase in financial depth indicating large portion of currency in developed economies. The implication of rising M2 is monetization instead of financial depth (Demetriades and Hussein, 1996). More, Liquid Liabilities (LLY) is more relevant indicator of financial development (Rousseau and Wachtel, 2000; Rioja and Valev, 2004; Levine et al., 2000) since it measures the overall size of the financial intermediary sector due to the fact that it includes central bank, deposit money banks and other financial institutions.

In addition to the measure of financial development, this study uses financial openness, trade openness and foreign direct investment as explanatory variables.

The following indicators are calculated from the data following different studies in the literature. The first ratio for financial development is calculated, following King and Levine (1993), as a ratio of the claims on the private sector by deposit money banks and other non-bank financial institutions in GDP. It will be called PRIVO from now on. The contribution of this indicator is to remove the credits issued to the private sector as opposed to credit issued to governments and public enterprises. Furthermore, it measures the credit issued by intermediaries other than the central bank. It is a measure of the intensity of government interference in bank lending decisions. It is a very good proxy variable for financial depth.

Following King and Levine (1993), another financial development indicator is related with liquidity. The ratio of liquid liabilities to GDP, which is equal to currency plus demand and interest-bearing liabilities of banks and other financial intermediaries divided by GDP, is used as the measure of the absolute size of the banking sector based on liabilies. This ratio includes all financial sectors therefore it is called the broadest available indicator of financial intermediations. It is a called financial "depth" measurement for the size of the financial sector. It is nominated as M2 in the study.

As financial openness indicators, this study follows the variables created by Creane et al. (2003). Creane et al. (2003) uses the ratio of gross private capital flows to GDP. It calculates the sum of the direct, portfolio and other investment inflows and outflows in absolute values, however, it excludes changes in the assets and liabilities of monetary authorities and general government. It is denominated as FO in the study. As an another indicator for the foreign direct investment, it is calculated as the sum of the absolute values of inflows and outflows of foreign direct investment recorded in the balance of payments financial account, including reinvestment of earnings, equity capital, other long-term capital and shortterm capital. This measurement captures inward and outward investment, where the standard FDI measurement indicates only inward investment. The ratio of foreign direct investment to GDP is denoted as FDI in this study. 
The next indicator is for trade openness, following Creane et al. (2003), which is calculated as the ratio of sum of the import and export in absolute value in GDP. Do and Levchenko (2004) and Huang and Temple, 2005) show that trade openness indicator is mostly used to show the financial development increase in the developing economies.

\section{Methodology}

Pesaran et al. (1999) modeled the autoregressive distributed lag (ARDL) approach to cointegration. Then, Pesaran et al. (2001) developed bound testing approach to cointegration to reveal the possible long-run relationship between variables. The reason of using ARDL model in this study is that ARDL methodology has several advantages over other techniques of cointegration. Mostly two cointegration techniques used in the literature to examine the long run relationship among variables. These are namely Engle and Granger (1987) estimation of cointegration by the two-stage estimation and Johansen (1988) and Johansen and Juselius (1990). However, ARDL approach has several advantages over these two other suggested methodologies. First, ARDL is used for any integrated variables-either $I(0), I(1)$, or/and a combination of both, fractionally integrated, or mutually co-integrated. Second, it considers plenty lags to seize the data generating process in general to specific modeling frameworks (Laurenceson and Chai, 2003). Third, the error correction model can be easily extracted from ARDL models by using a simple linear transformation to incorporate short run adjustments with long run equilibrium. Fourth, ARDL approach gives better the small sample properties than other cointegration techniques (Pesaran et al., 1999; Caporale and Pittis 2004). Fifth, endogeneity is not an issue in the ARDL technique. For this purposes, Pesaran et al. (1999) show that the serial correlation and endogeneity problems are fixed by choosing the correct lags in the ARDL model. The last one advantage of ARDL method is that it can easily choose the correct variable between dependent and explanatory variables.

The following model specification gives the empirical relationship of the financial development to financial openness, trade openness and foreign direct investment:

$$
P R I V O_{t}=\beta_{0}+\beta_{1} F O_{t}+\beta_{2} T O_{t}+\beta_{3} F D I_{t}+u_{t}
$$

where, PRIVO denotes a proxy for financial development, FO denotes financial openness, TO denotes trade openness and FDO demotes foreign direct investment.

The possible relationship in levels of the variables in Equation (1), the bounds testing approach found by Pesaran et al. (2001) is applied. There are two stages in the bounds testing procedure. The first one includes to create a long-run relationship between the variables. Once a long-run relationship has been established, then a twostep method is used to release the long-run relationship depending on the autoregressive distributed lag approach.

The theory proves that there is a long-run relationship among the variables $y$ and $x$. In this study, $y$ characterizes financial development proxy variables and $x$ characterizes the three explanatory variables of financial openness, trade openness or foreign direct development proxies. To be precise, the bounds testing approach follows an unrestricted error-correction model by using each of the variables as a dependent variable in every estimation. This method does not use any prior information to determine the direction of the long-run relationship among the variables. For instance, error correction model is used when financial development proxy variable, PRIVO, the ARDL methodology contains the estimation of the following model:

$$
\begin{aligned}
& \Delta \mathrm{PRIVO} O_{t}=\beta_{0}+\beta_{1} D_{T B}+\sum_{i=1}^{p} \lambda_{i} \Delta \mathrm{PRIVO} O_{t-i} \\
& +\sum_{i=1}^{p} \omega_{i} \Delta \mathrm{FO}_{t-i}+\sum_{i=1}^{p} \phi_{i} \Delta \mathrm{TO}_{t-i}+\sum_{i=1}^{p} \gamma_{i} \mathrm{FDI}_{t-i} \\
& +\delta_{1} \text { PRIVO }_{t-1}+\delta_{2} F O_{t-1}+\delta_{3} T O_{t-1}+\delta_{4} F D I_{t-1}+u_{t}
\end{aligned}
$$

where, $\beta_{0}$ is constant term, $\beta_{1}$ is the dummy for structural break and $u_{t}$ denotes the white noise. The terms with summation signs represent the error correction dynamics and $\gamma_{i}$ 's belongs to the long run relationship. In the ARDL bounds test approach, first test the existence of a long-run relationship among the variables using F-tests. In other words, estimate Equation (2) using ordinary least squares first. Second, by employing the co-integration test in the Equation (2) $\left(H_{0}: \delta_{1}=\delta_{2}=\delta_{3}=\delta_{4}=0\right)$, the non existence of long-run relationship against the alternative of a longrun levels relationship $\left(H_{1}: \delta_{1} \neq 0 ; \delta_{2} \neq 0 ; \delta_{3} \neq 0 ; \delta_{4} \neq 0\right)$ is performed as a Wald restriction test.

The asymptotic distributions of the $\mathrm{F}$-statistics are non-standard under the null hypothesis of no cointegration between the variables in the unrestricted error correction model given in Equation (2), whether the variables are purely $I(0)$, purely $I(1)$, or mutually cointegrated (Pesaran et al., 2001). Pesaran et al. (2001) provide two sets of asymptotic critical values for the all variables are assumed to be $I(0)$ and $I(1)$, respectively. The null hypothesis of no cointegration is rejected if the computed $F$-statistics is greater than the upper bound critical value and following this result the conclusion is to existence of a long-run equilibrium among the variables. If the computed $F$-statistics is less than the lower bound critical value, then the null hypothesis of no cointegration cannot be rejected. The other conclusion might end with inconclusive bound testing result, when the computed $F$-statistics falls within the lower and upper bound critical values. 
The ARDL method estimates $(p+1) k$ number of regressions, where $\mathrm{p}$ is the maximum number of lags and $\mathrm{k}$ is the number of variables in the equation, to choose the optimal lag length for each variable. By using Schwartz-Bayesian Criteria and Akaike's Information Criteria, the appropriate model is chosen.

After confirming the existence of a long-run relationship in the first step, then two-step procedure can be employed. In the second step, a conditional autoregressive distributed lag model, $\operatorname{ARDL}(p, q)$, for $P R I V O$ can be estimated as follows:

$$
\begin{aligned}
& \text { PRIVO }_{t}=\beta_{0}+\beta_{1} D_{T B}+\sum_{i=1}^{p} \omega_{i} F O_{t-i} \\
& +\sum_{i=1}^{p} \phi_{i} T O_{t-i}+\sum_{i=1}^{p} \gamma_{i} F D I_{t-i}+u_{t}
\end{aligned}
$$

When a long run relationship exists among the variables, there is an error correction representation is added in the model. The ARDL model can be reparametrized to produce an error correction model. After confirming the long-run relationship among the variables, the error correction model is estimated as below:

$$
\begin{aligned}
& \Delta P R I V O_{t}=\beta_{0}+\beta_{1} D_{T B_{c}}+\sum_{i=1}^{p} \lambda \Delta P R I V O_{t-i}+\sum_{i=1}^{p} \omega_{i} \Delta F O_{t-i} \\
& +\sum_{i=1}^{p} \phi_{i} \Delta T O_{t-i}+\sum_{i=1}^{p} \gamma_{i} \Delta F D I_{t-i}+\theta E C M_{t-1}+u_{t}
\end{aligned}
$$

where, $\lambda_{i}, \omega_{i}, \phi_{I}$ and $\gamma_{i}$ are short-run parameters; $\theta$ is the speed of adjustment. The error correction model result shows adjustment speed back to long-run equilibrium after a possible short-run shock.

\section{Empirical Results}

The variables are tested by ADF test for stationarity to see whether they are integrated $I(0), I(1)$ or fractionally cointegrated, although the ARDL bounds testing procedure can be run regardless of the results. The bounds test can be applied only to the $I(0)$ or $I(1)$ series. Since the series are not integrated $I(2)$, Pesaran et al. (2001) test statistics can be used. It can be seen from Fig. 1 that some data is non-stationary or stationary around a break. Therefore, structural break test of Zivot and Andrews (1992) is applied. The results in Fig. 2 shows the Zivot and Andrew (1992) structural break test $\mathrm{t}$-statistics. The results shown in Table 1 suggest that none of the variables is integrated of order 2 or above. Zivot and Andrews (1992) suggest a tree possible break in the series: Model A allows for a change in the intercept, Model B allows for a change in the trend, Model $\mathrm{C}$ allows for a change in both intercept and slope (For detailed model definitions, Zivot and Andrews (1992). Table 2 summaries the result of ZA structural break test. There is a structural break in Financial Openness (FO) and Financial Development (FDO) series in 32nd and 34th observation, respectively. We follow Narayan (2005) and Acikgoz et al. (2012) and add structural change dummy at the ARDL model. Structural break dummy defined as $D T B=1$ if $t>T B$; 0 otherwise (We calculate ARDL model with structural dummy for 32nd observation and the results did not change). Considering the financial crisis happened in 2008, we take time break as 35th observation (2007).

Next step, the ARDL bounds testing procedure is applied to see the existence of the long-run relationship. Therefore, Equation (2) is estimated by the OLS. The calculated F-statistic is found as 4.7436; and it is greater than the upper critical values. It can be concluded that there is strong evidence of a long-run relationship among the considered variables (Narayan (2005) examines the small sample problem within the context of the bounds testing approach. He generates the critical values for the test statistics (the F-statistics) to accommodate small sample sizes. The present paper uses the critical values of the F-statistics modified by Narayan (2005), as we have 40 observations (T). According to Narayan (2005) critical values for the bound test, case IV for $\mathrm{k}=4$ is 3.5 and 4.587 at $5 \%$ for $\mathrm{n}=40$ ).

Equation (3) is estimated by using ARDL methodology. There are $(4+1)^{\wedge} 4=625$ regression estimation. By following The Swartz Information Criterion (SIC), the ARDL model is selected as $(2,4,0,0)$. The results are given in Table 3 . The coefficient of FO, TO and FDI and are 3.06, -0.016 and 2.24 respectively and statistically significant, except TO. The estimation result shows that financial development measurement, which is proxied by private credits by commercial banks to gdp, will increase by 3.06 and $2.24 \%$ for a one percent increase in financial openness and foreign direct investment, respectively. These results indicate that Turkey's financial development can be attributed to financial openness, as well as to an increase in foreign direct investment. On the other hand, it cannot be predicted by trade openness. Table 3 shows that the estimated model is validated by the diagnostic tests of serial correlation, functional form specification, but not normality and heteroskedasticity.

Table 4 summarizes the short-run dynamics of financial openness, trade openness and foreign direct investment. $\triangle \mathrm{FO}$ and $\triangle \mathrm{FDI}$ are significant at $5 \%$ level of significance. The error correction coefficient, $E C M_{t-1}$, has negative and correct sign; and suggests that nearly $69 \%$ of the disequilibria in GDP growth of the previous year's shock adjust back to the long-run equilibrium in the current year. $R^{2}$ shows that the estimated model has a good fit. 
PRIVO

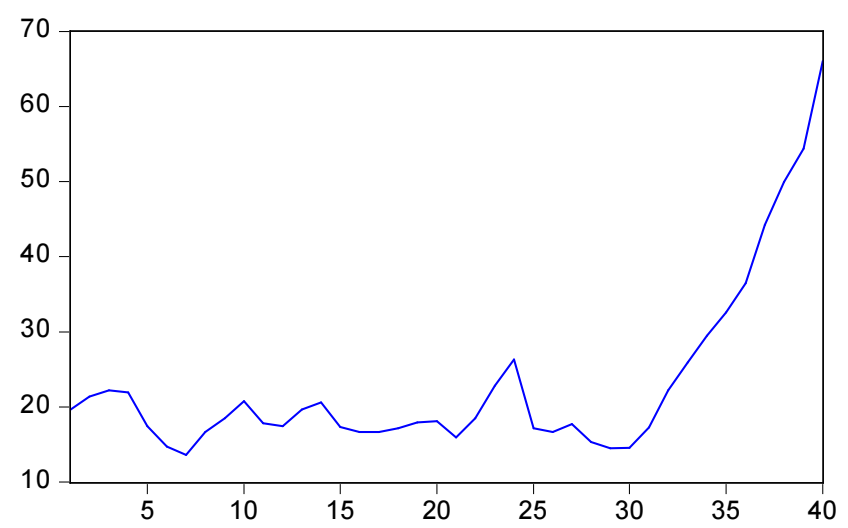

FO

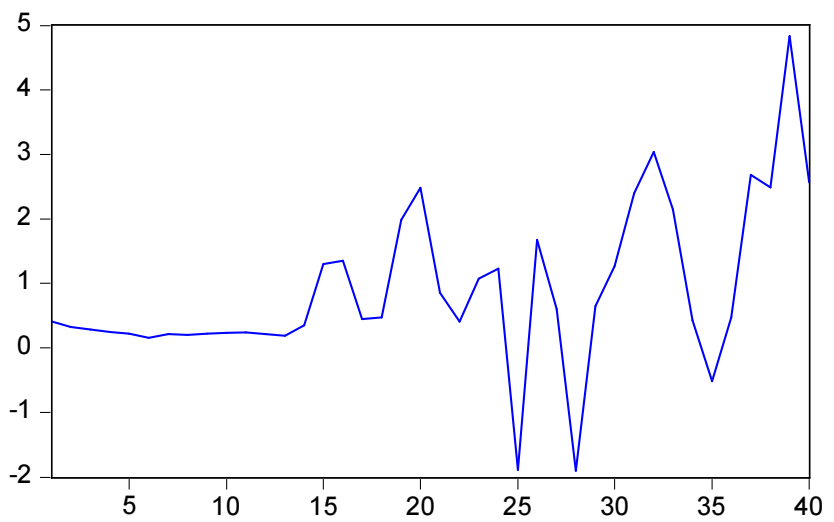

FDI

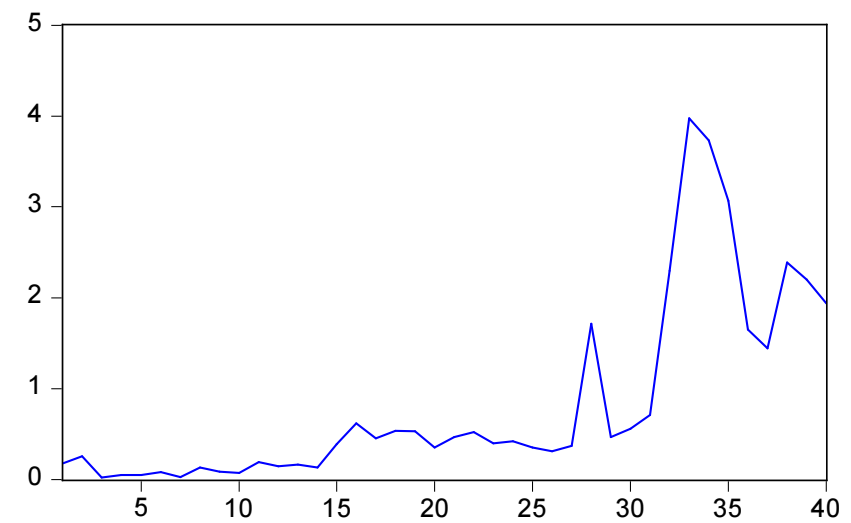

TO

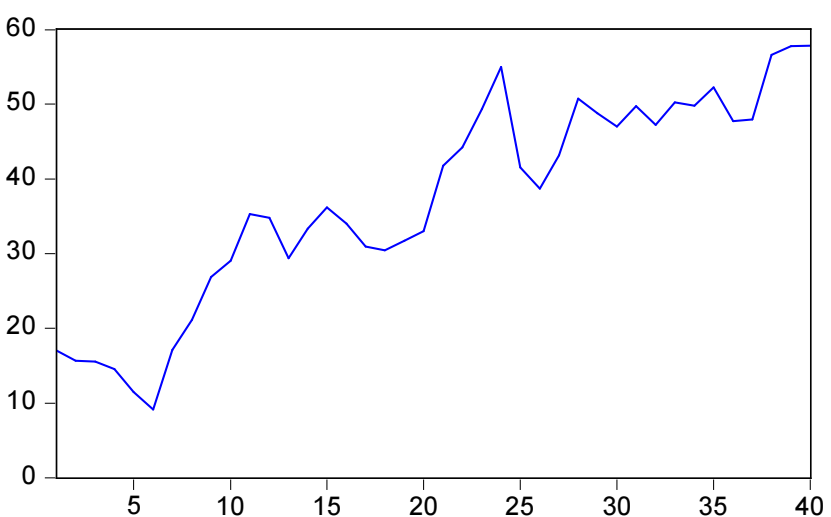

Liquid Liabilities(LL)

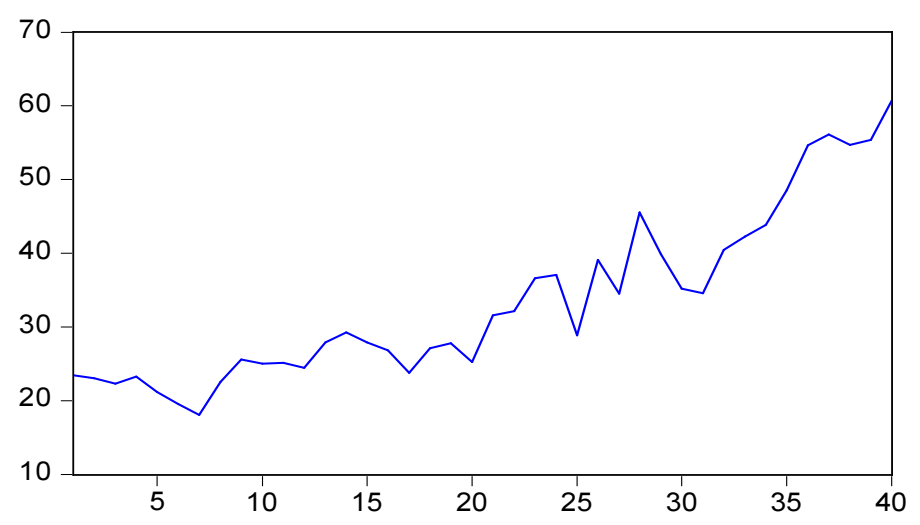

Fig. 1: The time series plot of FDI, financial openness, trade openness and prxies of financial development data

The empirical results suggest that financial openness and foreign direct investment have an effective role in promoting financial development. On the other hand, trade openness has no impact on financial development. These results support the empirical results of Chinn and Ito (2006) and Baltagi et al. (2009), where trade openness is not a strong predictive variable for financial development, but financial openness is a better predictive variable on financial development. It can be concluded that financial openness and foreign direct investment as a financial development policy can be used to foster financial development and economic growth. These results has very important implication on the Turkey's Custom Union agreement with the European Union. 

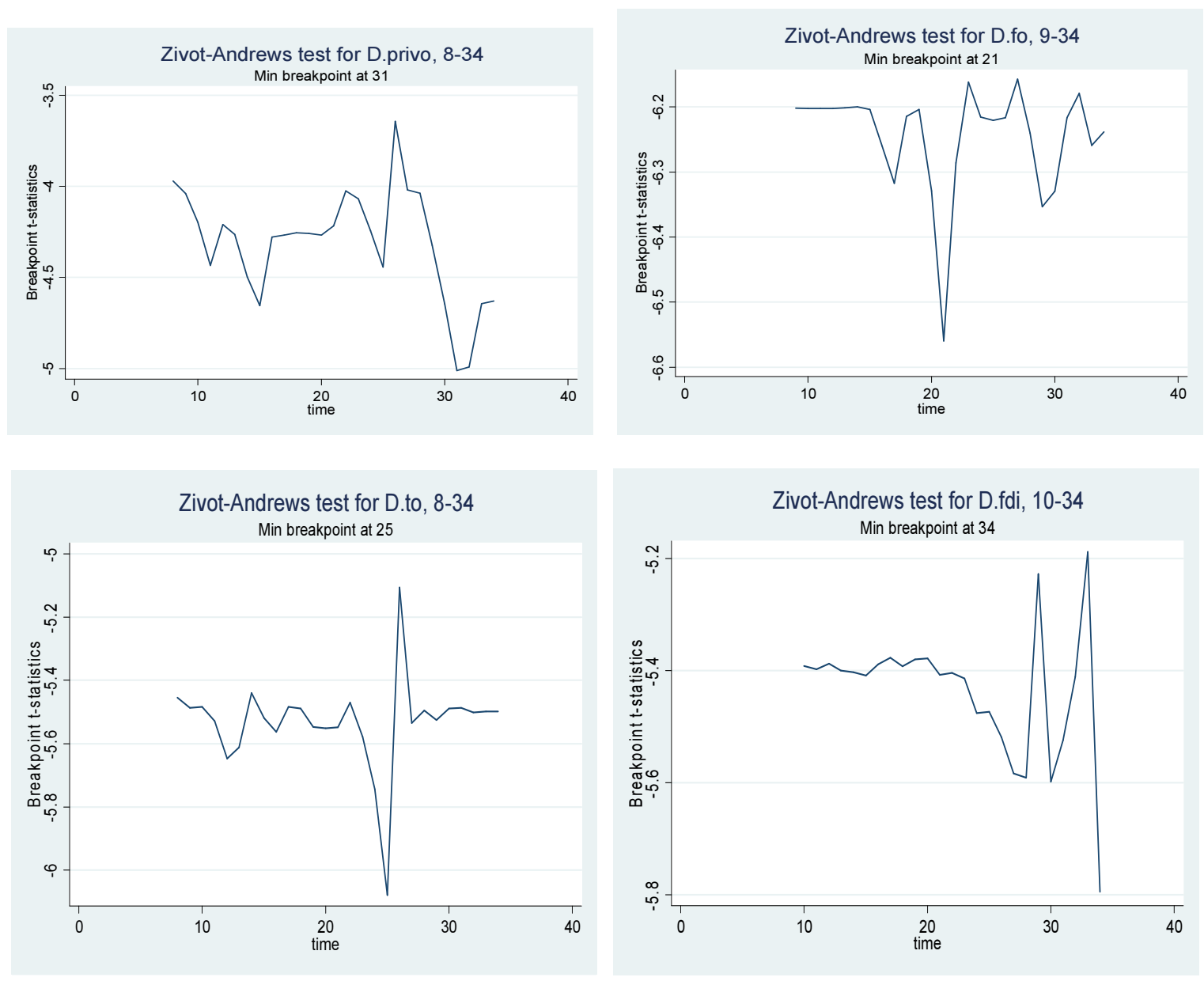

Fig. 2: Zivot andrews structural break test

Table 1: Unit root test

\begin{tabular}{|c|c|c|c|c|}
\hline & \multicolumn{2}{|c|}{ ADF with intercept and trend } & \multicolumn{2}{|c|}{ ADF First Difference with intercept } \\
\hline & $\tau_{\tau}$ & $\mathrm{k}$ & $\tau_{\mu}$ & $\mathrm{k}$ \\
\hline$\overline{\mathrm{PRIVO}}$ & 2.27 & 1 & $-4.02 *$ & 0 \\
\hline LL & -1.6 & 1 & $-3.7 *$ & 0 \\
\hline FO & $-4.37 * * *$ & 0 & $-5.01 *$ & 0 \\
\hline TO & -2.69 & 1 & $-5.18 * * *$ & 0 \\
\hline FDI & $-3.56^{*}$ & 1 & $-8.67 * * *$ & 0 \\
\hline
\end{tabular}

Augmented Dickey-Fuller (ADF) statistics for testing the null of a unit root against the alternatives of level stationary $(t \mathrm{~m})$ and trend stationary $(t t)$. Critical values without trend $(t m):-2.87(5 \%)$ and $-3.43(1 \%)$ for ADF. Critical values with trend $(t m):-3.41$ $(5 \%)$ and $-3.96(1 \%)$ for ADF. ${ }^{*}$ denotes a rejection of the null hypothesis, $k$ denotes the lag length chosen by SIC

Table 2. Zivot-andrews structural break unit root test

\begin{tabular}{|c|c|c|c|c|c|c|c|c|}
\hline \multirow[b]{2}{*}{ Series } & \multirow{2}{*}{$\begin{array}{l}\mathrm{ZA}^{\mathrm{a}} \text { Intercept } \\
-\mathrm{Min} \text { t-stat } \\
\end{array}$} & \multicolumn{3}{|c|}{$\mathrm{ZA}^{\mathrm{b}}$ Trend } & \multicolumn{2}{|l|}{$\mathrm{ZA}^{\mathrm{c}}$ Both } & \multicolumn{2}{|l|}{ Difference } \\
\hline & & $T B$ & Min $t$-stat & $T B$ & Min $t$-stat & $T B$ & Min $t$-stat & $T B$ \\
\hline$\overline{\text { PRIVO }}$ & 0.731 & 34 & -2.9 & 33 & -2.93 & 33 & -5.01 & 31 \\
\hline FO & -4.795 & 21 & $-4.813^{*}$ & 29 & $-5.368^{*}$ & 34 (2007) & $-6.5^{* *}$ & 21 \\
\hline TO & $-4.719_{* *}$ & 9 & -4.04 & 12 & -4.380 & 32 & -3.9 & 32 \\
\hline FDI & $-6.800^{* 3}$ & 32 & $-4.125 *$ & 25 & $-7.620^{* *}$ & $32(2005)$ & $-5.794^{* *}$ & 34 \\
\hline M2 & -4.250 & 34 & $-4.918^{*}$ & 32 & -5.035 & 30 & $-5.33^{*}$ & 34 \\
\hline
\end{tabular}

${ }^{\mathrm{a}}$ Break in intercept. Critical values are -5.53 and -4.80 for $1 \%$ and $5 \%$ significance level, respectively ${ }^{\mathrm{b}}$ Break in trend. Critical values are -4.93 and -4.42 for 1 and $5 \%$ significance level, respectively. ${ }^{c}$ Break in intercept and trend. Critical values are -5.57 and -5.08 for 1 and $5 \%$ significance level, respectively. TB stands for time break. ${ }^{* *} ;{ }^{*}$ shows the series is stationary around a structural break around mean, trend or both at 1 and $5 \%$ level, respectively 
Table 3: ARDL model: Long run results

\begin{tabular}{lll}
\hline Dependent variable: $P R I V O$ & & $T$-Values \\
\hline Regressor & Coefficient & $2.08^{* *}$ \\
\hline FO & 3.06 & -0.27 \\
TO & -0.016 & $2.62^{* *}$ \\
FDI & 2.24 & $12.2^{* * *}$ \\
DTB & 8.74 & $7.32^{* * *}$ \\
constant & 16.0 & $p$-values \\
Diagnostic test statistics & Test-statistics & 0.748 \\
$\chi^{2} \operatorname{sc}(1)$ & 0.10 & 0.981 \\
$\chi^{2}$ ff(1) & 0.00057 & 0.519 \\
$\chi^{2}$ nor(1) & 1.31 & 0.528 \\
$\chi^{2}$ het $(1)$ & 0.39 & \\
F stat: 5.2539 & & \\
\hline
\end{tabular}

Notes: ARDL $(2,4,0,0)$ selected on the basis of SIC, $\chi^{2} \operatorname{sc}(1), \chi^{2} \mathrm{ff}(1), \chi^{2} \operatorname{nor}(1)$ and $\chi^{2}$ het(1) denote $t$-statistics for serial correlation, functional form, normality errors and heteroskedasticity, respectively

Table 4: ARDL model ECM results ARDL $(2,4,0,0)$ selected based on SBC

Dependent variable: $P R I V O$

\begin{tabular}{|c|c|c|}
\hline Regressor & Coefficient & $t$-values \\
\hline$\overline{\Delta \mathrm{PRIVO} 1}$ & 0.47391 & $2.44^{* *}$ \\
\hline$\Delta \mathrm{FO}$ & 0.6325 & 1.658 \\
\hline$\Delta \mathrm{FO} 1$ & -2.0825 & $-2.712^{* *}$ \\
\hline$\Delta \mathrm{FO} 2$ & -2.0882 & $-3.846^{* * *}$ \\
\hline$\Delta \mathrm{FO} 3$ & -1.0315 & $-2.273^{* *}$ \\
\hline$\Delta \mathrm{TO}$ & -0.114 & -0.273 \\
\hline$\Delta \mathrm{FDI}$ & 1.5541 & $2.55^{* *}$ \\
\hline DTB & 6.045 & $4.49^{* * *}$ \\
\hline $\operatorname{ECM}(-1)$ & -.6914 & $-4.03^{* * *}$ \\
\hline \multicolumn{3}{|c|}{ Diagnostic test statistics } \\
\hline$R$-squared & 0.76 & \\
\hline $\mathrm{F}(9,26)$ & $8.85 * * *$ & \\
\hline DW & 2.03 & \\
\hline
\end{tabular}

$E C M=\mathrm{PRIVO}-3.589 * \mathrm{FO}+0.01656 * \mathrm{TO}-2.2476 * \mathrm{FDI}-8.742 \mathrm{DT}-16.0321 *$ Constant

\section{Conclusion}

This study examines whether the intensity of financial and trade openness and foreign direct investment promoted financial development in emerging economies over the period of 1974 to 2014 in Turkey by using three financial development indicators, financial openness, trade openness and foreign direct investment. The time-series Autoregressive Distributed Lag model (ARDL) and the bounds tests of Pesaran et al. (2001) is performed. The empirical results suggest that financial openness and foreign direct investment have an effective role in promoting financial development. On the other hand, trade openness has no impact on financial development. It can be concluded that financial openness and foreign direct investment can be used as a financial development policy tool to stimulate financial development and therefore economic growth in Turkey. These results has very important inferences on the Turkey's Custom Union agreement with the European Union.

\section{Acknowledgement}

We express our gratitude to the reviewers and the editor for valuable comments that help improve the article.

\section{Ethics}

This article is original and contains unpublished material. The corresponding author confirms that the other author have read and approved the manuscript and no ethical issues involved.

\section{References}

Acikgoz, S., M. Balcilar and B. Saracoglu, 2012. Openness and financial development: Time series evidence for Turkey. Int. J. Bank. Account. Finance, 4: 172-201.

Acikgoz, S. and M. Mert, 2014. Sources of growth revisited: The importance of the nature of technological progress. J. Applied Econom., 17: 31-62. DOI: $10.1016 / \mathrm{S} 1514-0326(14) 60002-7$. 
Baltagi, B.H., P.O. Demetriades and S.H. Law, 2009. Financial development and openness: Evidence from panel data. J. Dev. Econom., 89: 285-296. DOI: $10.1016 /$ j.jdeveco.2008.06.006

Beim, D.O. and C.W. Calomiris, 2001. Emerging financial markets. Irwin Professional Pub.

Borensztein, E., J. De Gregorio and J.W. Lee, 1998. How does foreign direct investment affect economic growth? J. Int. Econom., 45: 115-135. DOI: $10.1016 / \mathrm{S} 0022-1996(97) 00033-0$

Caporale, G.M. and N. Pittis, 2004. Estimator choice and Fisher's paradox: A Monte Carlo study. Economet. Rev., 23: 25-52. DOI: 10.1081/ETC-120028835

Chinn, M.D. and H. Ito, 2002. Capital account liberalization, institutions and financial development: Cross country evidence. National Bureau Econom. Res.

Chinn, M.D. and H. Ito, 2005. Current account balances, financial development and institutions: Assaying the world 'savings glut'. National Bureau Econom. Res.

Chinn, M.D. and H. Ito, 2006. What matters for financial development? Capital controls, institutions and interactions. J. Dev. Econom., 81: 163-192. DOI: 10.1016/j.jdeveco.2005.05.010

Creane, S., S.C.R.G.A. Mushfiq, M.R. Sab, R. Goyal and A.M. Mobarak et al., 2003. Financial Development in the Middle East and North Africa. 1st Edn., International Monetary Fund, Washington, ISBN-10: 1589062310, pp: 20.

Demirgüç-Kunt, A. and R. Levine, 1996. Stock markets, corporate finance and economic growth: An overview. World Bank Econom. Rev.

Demirgüç-Kunt, A. and V. Maksimovic, 1996. Stock market development and financing choices of firms. World Bank Econom. Rev., 10: 341-369. DOI: $10.1093 /$ wber/10.2.341

Demirguc-Kunt, A., H. Huizinga and S. Claessens, 1998. How does foreign entry affect the domestic banking market? World Bank Policy Res. Work. Paper.

Demetriades, P.O. and K.A. Hussein, 1996. Does financial development cause economic growth? Time-series evidence from 16 countries. J. Dev. Econom., 51: 387-411. DOI: 10.1016/S0304-3878(96)00421-X

Do, Q.T. and A.A. Levchenko, 2004. Trade and Financial Development. World Bank Policy Res. Work. Paper.

Engle, R.F. and C.W. Granger, 1987. Co-integration and error correction: Representation, estimation and testing. Econometrica J. Econometr. Society, 55: 251-276. DOI: $10.2307 / 1913236$

Hakkio, C.S. and M. Rush, 1991. Cointegration: how short is the long run? J. Int. Money Finance, 10: 571-581. DOI: 10.1016/0261-5606(91)90008-8

Huang, Y. and J. Temple, 2005. Does External Trade Promote Financial Development? 1st Edn., Centre for Economic Policy Research, London, pp: 25.
Huang, W., 2006. Emerging markets financial openness and financial development. Discussion Paper No. 06/588, Department of Accounting and Finance, University of Bristol. Bristol.

Johansen, S., 1988. Statistical analysis of cointegration vectors. J. Econom. Dynam. Control, 12: 231-254. DOI: $10.1016 / 0165-1889(88) 90041-3$

Johansen, S. and K. Juselius, 1990. Maximum likelihood estimation and inference on cointegration with applications to the demand for money. Oxford Bull. Econom. Stat., 52: 169-210.

Kaminsky, G. and S.L. Schmukler, 2002. Emerging market instability: Do sovereign ratings affect country risk and stock returns? World Bank Econom. Rev., 16: 171-195. DOI: 10.1093/wber/16.2.171

King, R.G. and R. Levine, 1993. Finance, entrepreneurship and growth. J. Monetary Econom., 32: 513-542.

Kim, D.H., S.C. Lin and Y.B. Suen, 2010. Dynamic effects of trade openness on financial development. Econom. Modell., 27: 254-261. DOI: 10.1016/j.econmod.2009.09.005

Klein, M.W. and G.P. Olivei, 2008. Capital account liberalization, financial depth and economic growth. J. Int. Money Finance, 27: 861-875. DOI: $10.1016 /$ j.jimonfin.2008.05.002

McKinnon, R.I., 2010. Money and Capital in Economic Development. 1st Edn., Brookings Institution Press, Brookings Institution, ISBN-10: 0815718497, pp: 184.

Levine, R., 1997. Financial development and economic growth: Views and agenda. J. Econom. Literature, 35: 688-726.

Levine, R., 2005. Finance and growth: Theory and evidence. Handbook Econom. Growth, 1: 865-934. DOI: $10.1016 / \mathrm{S} 1574-0684(05) 01012-9$

Levine, R., N. Loayza and T. Beck, 2000. Financial intermediation and growth: Causality and causes. J. Monetary Econom., 46: 31-77. DOI: $10.1016 / \mathrm{S} 0304-3932(00) 00017-9$

Laurenceson, J. and C.H. Chai, 2003. Financial Reform and Economic Development in China. 1st Edn., Edward Elgar Publishing, Cheltenham, ISBN-10: 1843767198, pp: 159.

Laeven, L., 2000. Financial liberalization and financing constraints: Evidence from panel data on emerging economies. World Bank, Financial Sector Strategy and Policy Department.

Narayan, P.K., 2005. The saving and investment nexus for China: Evidence from cointegration tests. Applied Econom., 37: 1979-1990. DOI: $10.1080 / 00036840500278103$

Ozturk, I. and A. Acaravci, 2013. The long-run and causal analysis of energy, growth, openness and financial development on carbon emissions in Turkey. Energy Econom., 36: 262-267. DOI: $10.1016 /$ j.eneco.2012.08.025 
Pesaran, M.H., Y. Shin and R.P. Smith, 1999. Pooled mean group estimation of dynamic heterogeneous panels. J. Am. Stat. Assoc. 94: 621-634. DOI: $10.1080 / 01621459.1999 .10474156$

Pesaran, M.H., Y. Shin and R.J. Smith, 2001. Bounds testing approaches to the analysis of level relationships. J. Applied Econometr., 16: 289-326. DOI: $10.1002 /$ jae.616

Petkovski, M. and J. Kjosevski, 2014. Does banking sector development promote economic growth? An empirical analysis for selected countries in Central and South Eastern Europe. Econom. Res., 27: 55-66. DOI: 10.1080/1331677X.2014.947107

Rajan, R.G. and L. Zingales, 2001. Financial systems, industrial structure and growth. Oxford Rev. Econom. Policy, 17: 467-482. DOI: 10.1093/oxrep/17.4.467
Rioja, F. and N. Valev, 2004. Finance and the sources of growth at various stages of economic development. Econom. Inquiry, 42: 127-140. DOI: $10.1093 / \mathrm{ei} / \mathrm{cbh} 049$

Rousseau, P.L. and P. Wachtel, 2000. Equity markets and growth: Cross-country evidence on timing and outcomes, 1980-1995. J. Bank. Finance, 24: 1933-1957. DOI: 10.1016/S0378-4266(99)00123-5

Shaw, E.S., 1973. Financial Deepening in Economic Development. 1st Edn., Oxford University Press, New York, pp: 260.

Svaleryd, H. and J. Vlachos, 2002. Markets for risk and openness to trade: How are they related? J. Int. Econom., 57: 369-395.

DOI: 10.1016/S0022-1996(01)00153-2

Zivot, E. and D.W. Andrews, 1992. Further evidence on the great crash, the oil-price shock and the UnitRoot. J. Business Econom. Statist., 10: 3-3. 